\title{
Dermatemys mawii Gray 1847 - Central American River Turtle, Tortuga Blanca, Hickatee
}

\author{
Richard C. Vogt ${ }^{1}$, John R. Polisar ${ }^{2}$, Don Moll ${ }^{3}$, \\ and Gracia Gonzalez-Porter ${ }^{4}$ \\ ${ }^{1}$ Coordinação de Biodiversidade, Instituto Nacional de Pesquisas da Amazônia (INPA), \\ Av. André Araújo 2936, Aleixo, CEP 69060-001, Manaus, Amazonas, Brazil [vogt@inpa.gov.br]; \\ ${ }^{2}$ Wildlife Conservation Society, 4841 1st Street, South, Arlington 22204 Virginia USA [jpolisar@wcs.org]; \\ ${ }^{3}$ Department of Biology, Southwest Missouri State University, Springfield, \\ Missouri 65804 USA [DonMoll@MissouriState.edu]; \\ 4331 Lincoln Ave., Takoma Park, Maryland 20912 USA [graciapgp@yahoo.com.mx]
}

Summary. - The Central American River Turtle, Dermatemys mawii, the single remaining extant species of the formerly wide-spread primitive family Dermatemydidae, is restricted to the Atlantic drainages of southern Mexico, Belize, and Guatemala. This large, highly aquatic, and totally herbivorous freshwater turtle is severely threatened throughout its range. There are older accounts citing specimens over $20 \mathrm{~kg}$ and carapace length of $60 \mathrm{~cm}$, but recent field studies have found few individuals in excess of $14 \mathrm{~kg}$ in Mexico or above $11 \mathrm{~kg}$ in Guatemala. The turtle's large size and highly palatable meat yield a high profit when the animals are sold at market. This has motivated hunters to overharvest many populations into extirpation. Although Dermatemys is consumed year-round, exploitation peaks during dry weather when low water levels facilitate capture. All forms of capture tend to select for larger size classes, thus not only reducing densities, but altering population structures, resulting in lower proportions of reproductively mature animals. The maturing cohort of smaller juveniles that remains is usually soon removed as well, resulting in unproductive populations in decline. Since Dermatemys is an herbivorous species and grows relatively fast, there is the possibility of raising this species in captivity or semicaptivity in polyculture systems with freshwater shrimp or ornamental fish. Even fast turtle growth rates would probably translate to a relatively slow cash return, suggesting that Dermatemys perhaps be a complementary species in a polyculture system. Where the capital and interest are sufficient, detailed and well-documented experiments testing the overall feasibility of these schemes are advised. However, captive propagation efforts should not distract critical funds and attention from the maintenance of wild stocks in their native habitats. Law enforcement is not the aswer to maintaining wild stocks, and habitat destruction by itself is not the problem - unless local people change their ways and stop eating or selling every Dermatemys they can, there is little chance of rehabilitating wild populations.

Distribution. - Belize, Guatemala, Mexico. Distributed in the Atlantic drainages of southeastern Mexico from central Veracruz through Tabasco, Chiapas, and Campeche, as well as throughout Belize and the Atlantic drainages of Guatemala, reaching the vicinity of the Honduras border.

Synonymy.-Dermatemys mawii Gray 1847, Emys mawii,Dermatemys mavei,Dermatemys mavii, Dermatemys mawi, Dermatemys mawei; Emys berardii Duméril and Bibron in Duméril and Duméril 1851, Ptychemys berardii, Clemmys berardii, Dermatemys berardii; Dermatemys abnormis Cope 1868, Chloremys abnormis; Dermatemys salvinii Gray 1870; Limnochelone micrura Werner 1901.

SubSPECIES. - None.

STATUS. - IUCN 2011 Red List: Critically Endangered (CR A2abd+4d) (assessed 2006); CITES: Appendix II.

Taxonomy. - Although 19 fossil genera of Dermatemydidae have been described, dating from the Jurassic of Europe and the Cretaceous of North America, Europe, and East Asia, Dermatemys mawii is the sole surviving genus and species (Romer 1956; Gaffney 1975, 1984; Iverson and Mittermeier 1980; Hutchison and Bramble 1981; Meylan 1987). The recognition of the species as distinct has been consistently unequivocal since the original description by Gray (1847), though its nomenclature has not, amassing many junior synonyms, none of which ever received widespread use.

There has been confusion in the literature about the correct spelling of both the specific name (mawii, mavei, mavii, mawi, or mawei) and the name of the collector (either Lt. Maw or Mawe), resulting in several unjustified emendations of the original and proper specific name, mawii (e.g., Cope 


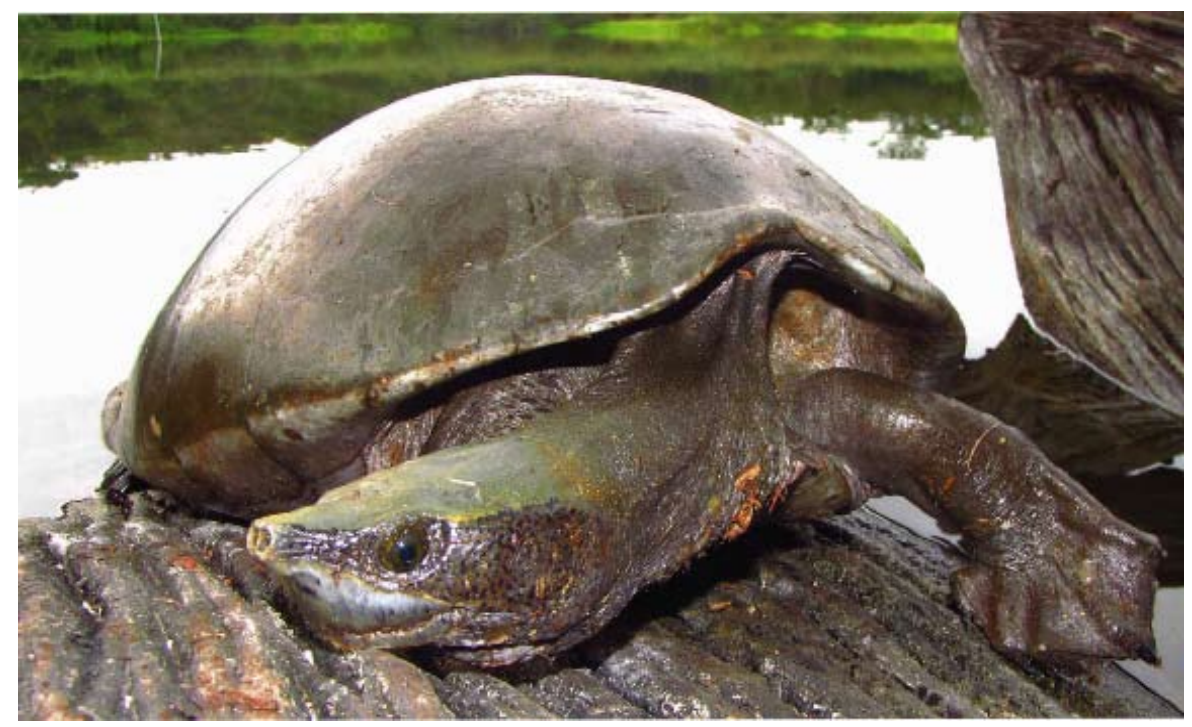

Figure 1. Adult female Dermatemys mawii from Laguna Peru in the Laguna el Tigre Reserve, Peten, Guatemala. Photo by Melvin Mérida, Wildlife Conservation Society.

1865; Bienz 1895; Neill and Allen 1959; Smith and Smith 1980). The most recent misspelling, Dermatemys mawei, was perpetuated by Smith and Smith (1980).

In the original description, Gray (1847) stated the name of the donor as "Mawe" and formulated the patronym "Dermatemys Mawii"; he used the name "Mawe" twice more
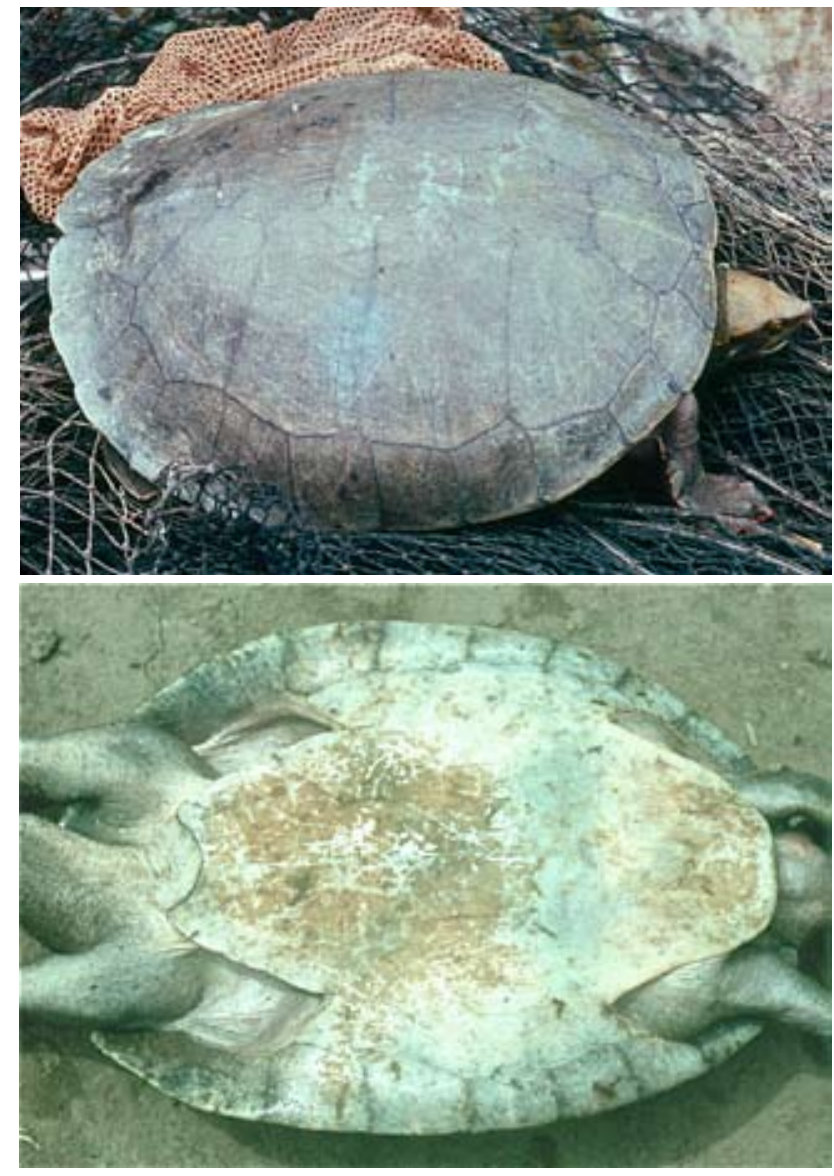

Figure 2. Adult male Dermatemys mawii from Rio Lacantun, Chiapas, Mexico. Photos by Richard C. Vogt.
(1856 and 1873) without mentioning an alternative spelling. However, all of the British Museum records and labels associated with the type specimen use the spelling "Maw". The following information was supplied by E.N. Arnold and Colin McCarthy of the British Museum (Natural History). The type specimen is BMNH 1947.3.4.12, a complete shell, CL $388 \mathrm{~mm}$ (420 mm measured over the curve) and is the specimen illustrated by Gray (1856: pl. XXI). Associated with or inscribed upon the type are: "Emys Mawi Lt. Maw R.N. Corr. Memb. S. America 1833". Written three times on the inside of the shell, in the same hand, is "Lieut Maw 1833". Records of the Zoological Society of London list Solomon Maw as a corresponding member for 1833-34.

Although there has been debate over the placement of Dermatemydidae in the superfamily Trionychoidea (Zug 1966; Gaffney 1975; Carr et al. 1981; Bickham and Carr 1983; Meylan 1987), all workers have agreed on a close relationship between the Kinosternidae and the Dermatemydidae. As the exact original provenance of the original type specimen was not known, Smith and Taylor (1950) restricted the type locality of D. mawii to Alvarado, Veracruz.

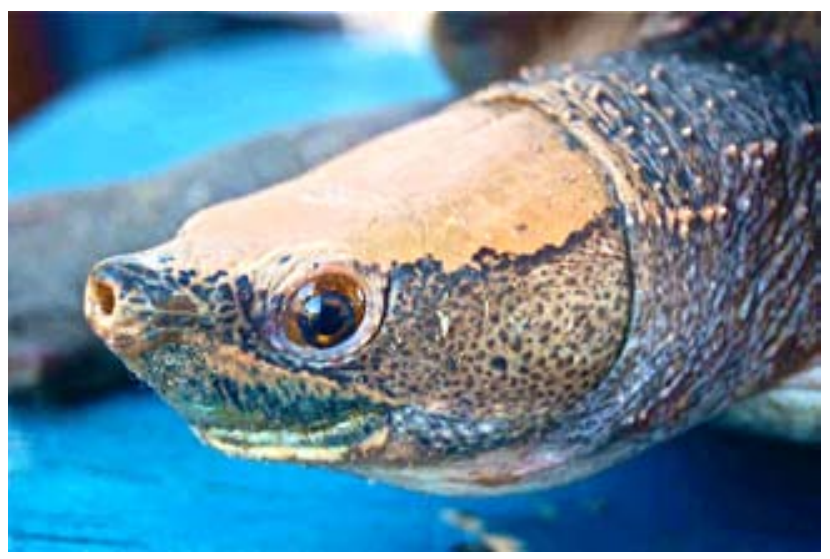

Figure 3. Adult male Dermatemys mawii from Big Falls, Belize River, Belize. Photo by Gracia Gonzalez-Porter. 


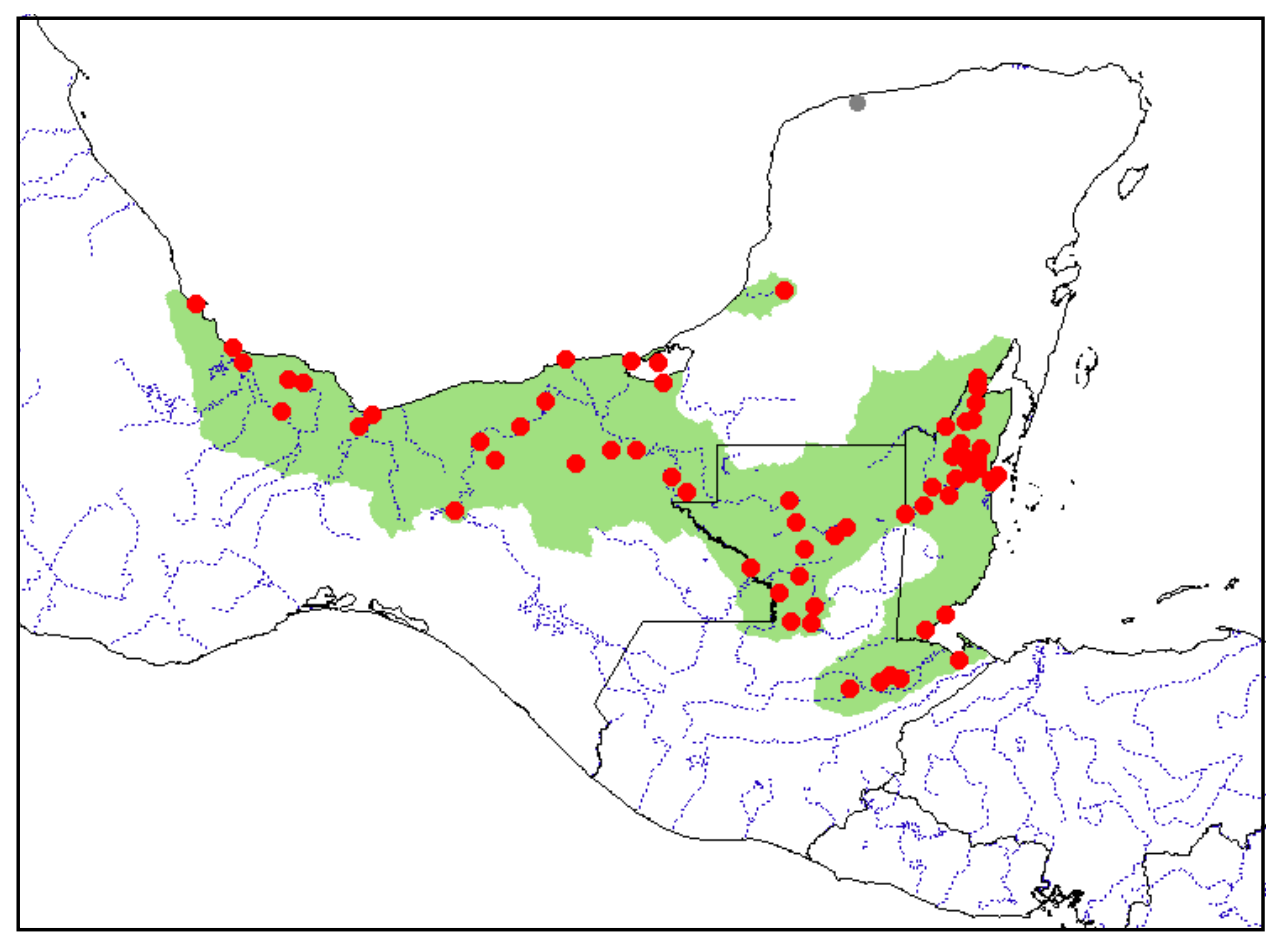

Figure 4. Distribution of Dermatemys mawii in southern Mexico, Belize, and Guatemala. Red dots = museum and literature occurrence records of native populations based on Iverson (1992), plus more recent and authors' data; gray dot = presumed introduced specimen; green shading $=$ projected distribution based on GIS-defined hydrologic unit compartments (HUCs) constructed around verified localities and then adding HUCs that connect known point localities in the same watershed or physiographic region, and similar habitats and elevations as verified HUCs (Buhlmann et al. 2009), and adjusted based on authors' data.

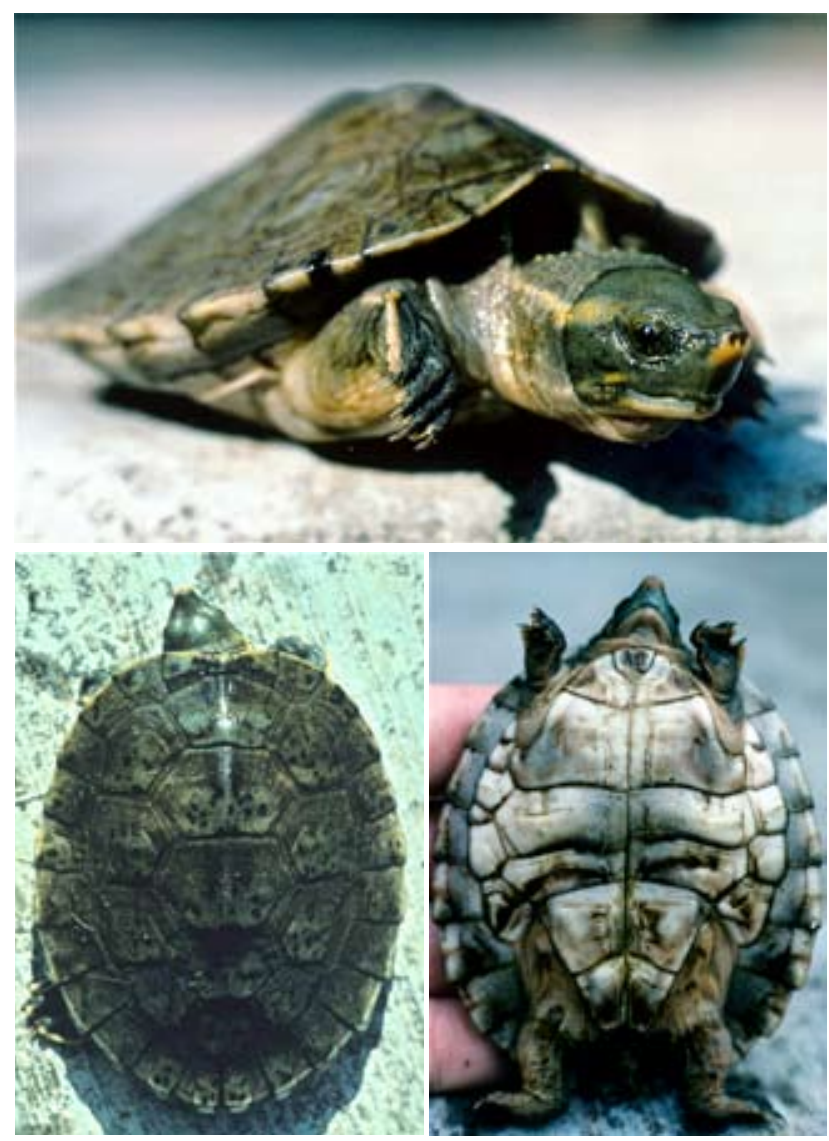

Figure 5.Juvenile Dermatemys mawii from Veracruz, Mexico. Note bright orange nostril coloration. Photos by Russell A. Mittermeier.
Gonzalez-Porter et al. (2011) conducted a phylogeographic analysis of $D$. mawii as part of a conservation management program for the species. Sampling 238 individuals from 15 different localities throughout the species' range, and using sequence fragments from the mtDNA Cyt $b$ and ND4 genes, they identified 16 different haplotypes. Their results revealed evidence of phylogeographic structure throughout the range, which appears to have been secondarily blurred by extensive gene flow. The divergence times of mtDNA haplotypes in D. mawii suggest that the main lineages split in the Pliocene-Pleistocene (3.73-0.227 MYA). One ancient genetic lineage (1D) was found to exhibit sequence divergence of up to $2 \%$ from the other lineages. Divergence of this magnitude is indicative of species level differentiation in other turtle genera. This highly divergent lineage 1D was found in only two localities, Sarstun, Guatemala, and Salinas, Mexico, but other individuals from other genetic lineages were also found in those localities. In addition, there was evidence of significant gene differentiation in individuals from a population at Papaloapan, Mexico.

These results suggest that human activity, such as harvesting and long distance transport of animals, may have influenced the current patterns of genetic diversity. For at least several thousand years, D. mawii has been consumed by people from Middle American cultures, and the archeological record contains strong evidence that the Mayans transported animals between villages and far away from their natural distribution range. 
Description. - Dermatemys mawii is a large freshwater turtle. Sizes of $600 \mathrm{~mm}$ straight carapace length (CL) and 22 $\mathrm{kg}$ have been reported in the past (Smith and Smith 1980; Iverson and Mittermeier 1980), although maximum sizes of $10-15 \mathrm{~kg}$ and CL of 450-500 $\mathrm{mm}$ are more common today (Polisar 1992, 1995, 1996).

There are significant differences between the minimum sizes at maturity of lagoon and river females and males (Polisar 1992). In general, females attain sexual maturity between 395-420 $\mathrm{mm} \mathrm{CL}$, while males become mature between 365-385 mm CL. The largest females (up to 500 $\mathrm{mm} \mathrm{CL}$ ) exceed the largest males (up to $466 \mathrm{~mm} \mathrm{CL}$ ) in size (Polisar 1992, 1996; Vogt, unpubl. data).

In general, the carapace is low, smooth, and broad, with a median keel in juveniles. In some older females, the arc of the carapace increases, resulting in relatively deep-bodied animals. The plastron is robust and connected to the carapace by a broad bridge. The hindlobe of the plastral margin is invaginated, more deeply in males. Three to six (usually 4 or 5) inframarginals separate the marginals from the 11 or 12 plastral scutes. In unusual cases there may be as many as 23 inframarginals. The gular scute may be divided or not. Twelve marginals are present on each side. Tooth-like longitudinal ridges are present on the alveolar surfaces of the maxilla, and the labial ridges are strongly serrated.

The carapace is uniform brown, nearly black, gray, or olive; the plastron is white, cream, or yellow.In some habitats the plastron may acquire a rust colored or dark brown stain from stream substrates. Skin and scute color vary among populations depending on habitat. In southern Mexico the limbs are brown or dark gray above and cream or lighter brown below.Polisar found that Dermatemys from the Belize River (a white water river; Sioli 1984; Payne 1986; Goulding 1980) had cream colored limbs, while animals from the sluggish darkwater tributaries had dark, almost black, limbs and axillary and inguinal pockets (Polisar 1992).

The dorsal head coloration of mature males is yellow, yellow-ochre, yellow orange, or even bright fluorescent orange, depending on the population (Polisar 1992). In some adult males the dorsal coloration is interspersed with black dots (e.g., Spanish Creek, Belize). The heads of males may also have dark black flecks laterally; that of females may be only slightly more yellow than the rest of the body.

Hatchlings weigh $18-35 \mathrm{~g}($ mean $=31.4, \mathrm{n}=40)$ and measure 51-58 mm in CL (mean $=54 \mathrm{~mm}, \mathrm{n}=40)$. Hatchlings differ from adults in having the tip of the nostrils bright orange to peach, this color gradually fades during the first several years of growth. In addition, the yellow orbital stripe is more distinct in hatchlings.

Distribution. - Dermatemys is found in the Atlantic drainages of southeastern Mexico from central Veracruz through the lowlands of the states of Tabasco, Chiapas, and Campeche. It also occurs throughout Belize where suitable habitat occurs, and in the Atlantic drainages of Guatemala, particularly in the departments of Peten and Izabal. The southern limit of the species appears to be in the vicinity of the Guatemalan-Honduran border, but this requires clarifi- cation (Alvarez del Toro et al. 1979; Iverson 1986, 1992). Dermatemys shares this basic distributional pattern with Staurotypus triporcatus, Claudius angustatus, and Kinosternon acutum (Polisar 1992). All four species are notably absent from the northern Yucatan Peninsula, although a recent record (Chablé-Santos et al. 2011) reported a specimen of D. mawii collected in the Municipality of Progreso, Yucatan, in a freshwater spring in a mangrove swamp. Since this habitat is entirely aberrant, and over $200 \mathrm{~km}$ from the nearest known population in Campeche, this animal was most probably introduced.

Habitat and Ecology. - Dermatemys is restricted to the larger deeper rivers and their tributaries, oxbow lakes, and lagoons in its range. Although it uses inundated forests and savannas during the rainy season, and may unintentionally get trapped in shallow water bodies when floodwaters recede, it is not a permanent resident of ephemeral wetlands, shallow marshes, or shallow rocky streams. By choice it occupies deep water with relatively cool temperatures (only temporarily exceeding $30^{\circ} \mathrm{C}$ ) and prefers access to soft substrates (Polisar 1992). In Belize it occupies habitats over 2.5-3.5 $\mathrm{m}$ in water depth, and usually over $6 \mathrm{~m}$ in depth.

This highly aquatic species is barely capable of locomotion on land. The only time it comes to shore is when the females crawl a few meters from the river bank to nest. Well oxygenated water is preferred, as they have highly vascularized papillae in the larynx (Winokur 1988) which enable them to stay underwater indefinitely, drawing water in through the mouth and exhaling through the nostrils. However, anaerobic blackwater oxbow lakes often develop large populations of Dermatemys that are trapped there after the water level of the river recedes in the dry season. Although Dermatemys will use fast-moving sections of rivers, they often seek respite from the current in the calmer parts of deep pools and in association with submerged woody debris imbedded in the river bottom. Larger animals usually rest at depth. When substrates are soft enough (in the absence of high velocity currents), adults may partially submerge themselves, with only the head visible. Small juveniles often seek shelter closer to the shore, resting partially imbedded in accumulations of detritus (Polisar 1992).

Populations inhabiting the more slow-moving creeks and lagoons in Belize reach first maturity at larger sizes than their counterparts in faster-moving rivers, and attain larger maximum sizes (Polisar 1992). Whereas ca. $70 \%$ of river males and females are reproductively mature at ca. 370 and $400 \mathrm{~mm} \mathrm{CL}$, respectively, in lagoons that same proportion is attained at between 380-390 mm CL in males and 410-420 $\mathrm{mm} \mathrm{CL}$ in females. The largest female caught in rivers was $<460 \mathrm{~mm}$ CL and the largest female caught in lagoons was $>480 \mathrm{~mm}$ CL (Polisar 1992). It is unclear whether this difference is a result of nutrition, temperature, or the energetic requirements of living in more rapidly flowing waters.

Dermatemys is completely herbivorous from hatchling to adult. Food habits vary among populations, apparently as a function of habitat characteristics. Belize populations that occur in clearwater habitats primarily subsist on submergent 
aquatic macrophytes (Polisar 1992).Populations in darkwater streams also make use of submergent vegetation during the dry season (Polisar 1992). Low water levels reduce access to shoreside emergents and terrestrial vegetation, and the aquatics flourish because reduced turbidity allows greater sunlight penetration. However, the prevailing pattern is one of animals that rest in deep water, then forage along the shoreline, grazing on grasses and the overhanging leaves and fruits of riparian trees and shrubs. In many rivers, the turbidity and velocity of the water during the seasonal floods prevents the development of any submergent aquatic vegetation, and the animals inhabit a fairly steep-sided stream channel lined with emergent vegetation and dense overhanging terrestrial vegetation. Since the water levels rise three or more meters seasonally in most habitats and as much as six to eight meters in some, the turtles become arboreal folivores and frugivores in the flooded forests during the wet season. Similarly, Dermatemys taken from seasonally flooded marshlands are often found to be feeding entirely on grasses.

Zentenoet al.(2010) conducted a detailed habitat survey of Dermatemys in Tabasco, Mexico, within the GrijalvaUsumacinta river basin in the Pantanos de Centla Biosphere Reserve (RBPC) during an annual cycle, and analyzed its relationship with several environmental variables. Water depth ranged from 0.25 to $>6.0 \mathrm{~m}$; during the rainy season water levels increased from 0.70 to $2.62 \mathrm{~m}$. Water current ranged from 0 to $1.05 \mathrm{~m} / \mathrm{sec}$, transparency of the water fluctuated from 0.08 to $1.81 \mathrm{~m}$, and water temperature from 20.6 to $33^{\circ} \mathrm{C}$. The three most common aquatic plants were Eichhornia crassipes, Pistia stratiotes, and Hydrocotyle umbelata. Riparian cover ranged from 0 to $95.2 \%$, and the most common terrestrial plants were Sabal mexicana, Haematoxylum campechianum, Coccolobabarnedensis, and Lonchocarpus sp.

Fruits are taken opportunistically when seasonally available (e.g., Ficus spp., Inga edulis), as are flowers, but the bulk of the diet of riverine Dermatemys consists of leaves from terrestrial trees and grasses. Moll (1989) reported estuarine populations using a mixture of mangrove leaves (Rhizophora mangle, Laguncularia racemosa, and Avicennia germinans) in southern Belize, and Polisar (1992) observed similar use of the red mangrove ( $R$. mangle) along the Rio Hondo branch, mixed in with species common to freshwater riparian forests.

In freshwater habitats Dermatemys usually forages nocturnally (Alvarez del Toro et al. 1979; Moll 1986, 1989). In areas under tidal influence animals are most active during a rising tide regardless of time of day (Moll 1986, 1989). A similar pattern is seen in freshwater habitats. Rising water (in response to local or upstream rainfall) stimulates foraging activity (Polisar 1992).

When water levels drop,Dermatemys occupying habitats lacking submergent vegetation will feed on piles of dead forest leaves that are entrapped behind $\log$ jams and in the calmer backwaters. This food supply is augmented by fresh leaf and fruit litterfall. Although Vogt (pers. obs.) felt that these turtles utilized these natural stockpiles of leaves to allow uninterrupted feeding throughout the year, Polisar (pers. obs.) speculated that the dry season constituted a time of nutritional hardship, and the wet season a time of nutritional plenty. This could be related to the timing of egg development, nesting, and hatchling emergence. Since fresh vegetation is accessible year-round in most lagoons and less accessible during the dry season in flowing streams, that is another possible explanation for the statistically significant differences between the body sizes of the turtles from lagoons and continuous flow streams (Polisar 1992).

Experiments have shown (Vogt,unpubl.data) that natural foregut flora and fauna helps Dermatemys break down plant material. Hatchlings allowed to inoculate their digestive system by feeding on adult feces for the first few days after hatching grew $30 \%$ faster in one year on the same diet of composite (mozote) Melanopodium than their clutch mates that were kept isolated from adults. The recorded increase in mass for one year was $159 \mathrm{~g} \pm 20.3$ (range 144-187 $\mathrm{g}, \mathrm{n}=$ 6 ) and $120 \mathrm{~g} \pm 17.1(95-142 \mathrm{~g}, \mathrm{n}=6)$, respectively, for the two treatment protocols. Although the organisms involved in the digestive process were not identified, they are perhaps similar to those described by Bjorndal and Bolten (1990) for Pseudemys nelsoni, an herbivorous species endemic to Florida. Under natural conditions the hatchlings might inoculate the gut by ingesting the nest substrate; females of most turtles discharge fluid from the cloaca in the process of nesting, and hatchlings of many species are found with nest substrate in the gut (Vogt, pers. obs.) Hatchlings could also simply inoculate the gut by feeding on adult feces, as in hatchling Green Iguanas (Troyer 1982). The small intestine of adults is usually packed with nematodes. Experiments need to be undertaken to determine if these nematodes act as parasites or commensals.

Dermatemys never basks, and popular account references to basking by floating on the surface of the water (Alvarez del Toro 1979) may actually refer to individuals with lung infections in captivity, or in the wild, which were having a hard time remaining under water. With its specialized gut symbionts, Dermatemys can digest plant material at lower temperatures than other turtles. In the Rio Lacantun and its tributaries, body temperatures of Dermatemys were found to be equal to that of the water, ranging from 23.5 to $32^{\circ} \mathrm{C}$ in an oxbow lake.

Shedding of all of the scutes occurs during the dry season in late April and May in Belize and Chiapas. In older individuals the scutes become fused and the shed scutes remain intact like a sloughed shell.

There is some disagreement on the timing of the nesting season, with some accounts describing a nesting season in March and April (Lee 1969; Moll 1986). The accounts that are based on more lengthy investigations report that nesting takes place primarily during the latter part of the rainy season (September through December), when water levels are at or near their annual peaks, and, secondarily, in the earliest part of the dry season (January through February), when water levels can be expected to recede. In north central Belize, 
Polisar $(1992,1996)$ encountered gravid $(n=14)$ females between late September and late November. He induced oviposition as late as mid-December. Despite an abundance of female reproductive organs collected between March and May, none bore shelled eggs or large corpora lutea. Thus, there was no evidence for a spring nesting season. However, the records provided by the corpora lutea and albicans of 28 adult females suggested that a small minority of the female population might lay eggs as late as February and early March. The Belize study, utilizing 50 hunters, reported shelled eggs collected from only two animals from over 100 slaughtered females in May. However, the hunters interpreted these two as anomalies.

Polisar's $(1992,1996)$ analysis of 51 adult male organs (testes and epididymides) indicated that breeding can take place from March through September. The proportion of breeding status males is low in March and April, and increases from early May into September. Mass copulation took place at night on 7 July 2002 in captivity at the Nacajuca turtle facility, involving all adult males; copulating pairs were noted floating at the surface of the water when workers arrived in the morning (Claudia Dick, pers. comm.). In Mexico, Vogt (unpubl. data) found that vitellogenesis begins in June and July, with oviposition taking place from September to March.

Nests are laid within $0-3 \mathrm{~m}$ of the shoreline, often in saturated soil. Because these nests are laid in scattered locations along a dynamic shoreline during the flood season, they are extremely difficult to locate, and consequently afforded some protection from human predation. The nests that are located often have been exposed by flood waters giving some locals the misconception that this species lays its eggs underwater. Both Vogt and Polisar found that the earliest nests of the season are often inundated for weeks at a time with no effect on hatching success. Polisar $(1992,1996)$ documented $80-100 \%$ hatching success in eggs subjected to 30+ days of submersion. The physiological mechanisms of this embryonic diapause are not known. Although it could be a simple extension of the pre-ovipositional diapause, Polisar $(1992,1996)$ found some eggs surviving drying and flooding sequences, suggesting the diapause may be more complex.

Vogt (unpubl. data) found that up to four clutches were laid per year in Chiapas. The number of eggs in 18 clutches from Chiapas and Veracruz averaged $14.8 \pm 3.37$ (range 10-24). Data on 121 eggs in 12 clutches from the Rio Tsendales and Rio Lacantun were: length $61.2 \pm 3.8 \mathrm{~mm}$ (range 56-67), width $36.4 \pm 2.9 \mathrm{~mm}$ (range 32-41), weight $49.4 \pm 10.1 \mathrm{~g}$ (range 37-72). Data on the 12 gravid females were: CL $466 \pm 34.5 \mathrm{~mm}$ (range 420-502), weight with eggs, $12,050 \pm 2545 \mathrm{~g}$ (range 9500-17,200), clutch weight $514.1 \pm 107 \mathrm{~g}$ (range 294-690), relative clutch mass 0.043 \pm 0.0098 (range 0.0294-0.0590).

Gonadal examination of mature females in Chiapas has suggested a mean potential of $2.6 \pm 1.06$ (range 1-4, n $=8$ ) clutches per year (Vogt, unpubl. data). In north central Belize, clutch frequency ranged from 0 to 4 , with a mean of
2.05. Only one out of 21 active females laid four clutches in a year. The extremes of clutch size $(n=49)$ were from 2 to 20 . Clutches over $15 \mathrm{eggs}$ were rare, and the mean was $10.98 \pm 3.68$. Total annual reproductive output varied from 0 to 47 eggs per year. Mean annual total reproductive output was $21(\mathrm{n}=27)$. In a sample of 44 oviductal and freshly laid eggs, the ranges of length, width, and mass were 54-72 $\mathrm{mm}, 36-50 \mathrm{~mm}$, and 34-70 g, respectively (Polisar 1992, 1996).

Polisar $(1992,1996)$ reported that total annual reproductive output increases with body size (CL). Since body size varies among populations, only within-population analyses can be valid. Isolating his Belize River sample he found the relationship to be strong among early breeders, and it was still significant among larger, older animals, but deteriorates, presumably due to variation in clutch frequency (Polisar 1992, 1996).

The eggs are brittle upon laying, but with advanced development in a high humidity substrate, the shell will crack and pulverize, leaving the turgid membrane covered with a powdery shell giving the impression that the shell is actually pliable. This accounts for the incongruency in the literature regarding the nature of the eggshell.

Vogt (unpubl. data) found that incubation time in the laboratory varied from 115-223 days, and attributed the variation to embryonic diapause and embryonic aestivation. Vogt and Flores-Villela (1992b) reported that incubation temperatures in the laboratory above $28^{\circ} \mathrm{C}$ produced all females and temperatures of $25-27^{\circ} \mathrm{C}$ produced males.

Dermatemys is essentially a winter nesting turtle of the subtropics (Polisar, unpubl. data). Eggs are laid at a time of the year when soil and water temperatures are decreasing. Belize River minimum temperatures are $20^{\circ} \mathrm{C}$ in November and December, when many clutches are underwater. Six simulated nests (containing actual Dermatemys eggs) in a cohune palm (Orbigyna cohune) forest bordering Spanish Creek experienced minimum daily mean temperatures of $22^{\circ} \mathrm{C}$ during January and February. These nests did not reach $26^{\circ} \mathrm{C}$ until late March and early April (Polisar 1992). Presumably the majority of embryonic development takes place in March, April, and May.

Diapause during flooding, followed by months of slow development due to low temperatures, might provide one explanation for confusion among earlier accounts regarding the nesting season. Eggs that appear recently laid in March may actually have been deposited in October. A second explanation may be due to contrasting environmental cues for reproductive chronology. Precipitation in the southeastern part of the turtle's range (along the Caribbean coast of southern Belize and Guatemala) is twice that in the north, and the dry season is less pronounced. Dermatemys occupying the estuarine habitats of the southern coast may follow a different reproductive calendar (Polisar 1992).

In the field, incubation periods are lengthy. Eggs may be laid as early as late September and October, development does not accelerate until March through May, and the hatchlings emerge in June and July, when the rainy season 
resumes. Polisar $(1992,1996)$ reported periods of 217-300 days between oviposition and hatchling emergence for six clutches. The periods he reported may exceed the average by approximately 30 days because the summer rains arrived one month later than normal. Hatchling emergence was correlated with the brief rains that punctuated the prolonged dry season.

The eggs and young of Dermatemys are consumed by coati (Nasua nasua), gray-necked wood rails (Aramides cajanea), raccoons (Procyon lotor), clapper rails (Rallus longirostris), limpkins (Aramus guarauna), and night herons (Butorides virescens, Nycticorax nycticorax and Nycticorax vilacea) (Moll 1986). Young and intermediate-sized animals are eaten by crocodiles (Crocodylus moreletii and Crocodylus acutus) (Smith and Smith 1980; Alvarez del Toro et al. 1982; Moll 1986). River otters (Lutra longicaudis) feed on hatchlings and subadults, and can be a serious threat to recruitment in some areas.

Population Status. - Dermatemys has been intensely persecuted throughout most of its range. It was once abundant in the Mexican states of Veracruz and Tabasco, but now individuals are hard to find (Vogt 1988, 1998). In the 1950s areas in Tabasco and Veracruz still had high concentrations of turtles, and hundreds were often caught in a single day by fishermen seining oxbow lakes. Market pressure brought them to such low numbers in Tabasco that fishermen from the city of Villahermosa moved on to Chiapas to exploit the abundant untapped populations there in the 1970s. Airstrips were built to ship them out and fishermen systematically decimated population after population until the numbers were so low that it was no longer economically feasible to pursue them. In general, the most intact Dermatemys populations are those that are more remote from human habitations, access points to waterways (such as bridges), and traditional human riverine travel routes. There were good populations in the Rio Lacantun and some of its remote tributaries within the Biosphere Reserve of Montes Azules (Vogt and Flores 1992a), but even those have now been extirpated. Scattered pockets exist throughout the Rio Usumacinta and in Campeche.

The status of Dermatemys populations in Belize varies depending on proximity to human habitations, ethnic/ cultural identity of the area (Creole, Mestizo, Garifuna, Maya, or Mennonite), hunting history, and inherent suitability of the habitat. Northern Belize is dominated by a broad coastal plain that is dissected by numerous rivers and lagoons. Southern Belize is dominated by the Maya Mountains and adjacent ranges. The southern coastal plain is narrow, and the rivers less lengthy, though some are still important. Some of the large Dermatemys waters of northern Belize are the Rio Hondo, the New River, the Belize River, the Sibun River, and the slow moving creeks, including Mussel Creek, Spanish Creek, and the Branch of the Hondo. All these Dermatemys habitats have a history of exploitation, but there is considerable variation in the intensity of that history. The Rio Bravo population has been subjected to recent exploitation, but was still in moderate condition in July of 1990 (Polisar 1992). The entire Rio
Bravo/Booths River population became protected by law (Statutory Instrument No. 55 of 1993). The main Hondo River has been exploited by both Mexicans and Belizeans, as has the Hondo Branch (though it is well inside Belize). The latter was in poor condition in November of 1990.

Moll (1986) worked in Progresso Lagoon in 1984 and felt that the status of that population was excellent. The proximity of that lagoon to Orange Walk Town and knowledge of professional hunters in Carmelita and San Esteban suggest to Polisar (pers. obs.) that the status has changed. Dermatemys was present in Honey Camp Lagoon, with netdestroying crocodiles (Crocodylus moreletii) minimizing exploitation there. In 1990, the population in the vast New River lagoon was still in good condition according to local informants working in the south end, but the north end had been subjected to considerable exploitation. The middle section of the lagoon has now been protected (Statutory Instrument No. 55 of 1993).

The Programme for Belize, a private conservation organization, owns the land surrounding the south end, thereby including it in the large Rio Bravo Conservation and Management Area (RBCMA). Irish Creek, a serpentine tributary of the New River Lagoon also harbors Dermatemys, and is also part of the RBCMA. Parts of Spanish Creek (classic deep water Dermatemys habitat) and all of Black Creek (smaller, but still important) are enclosed in the Crooked Tree Wildife Sanctuary, which has been managed by the Belize Audubon Society. Yet, until 1990, exploitation continued unabated in those creeks despite their legal status as part of the National Park System of Belize (Statutory Instrument No. 95 of 1984) due to a poorly resolved juxtaposition of parks and villages (Polisar 1992).

Dermatemys was still present and exploited in the entire Belize River in 1990. The densities were low in heavily exploited areas and adults scarce. In more remote, less heavily exploited areas, the status was much better (Polisar 1992, 1995). One of those remote sections became entirely protected (Statutory Instrument No. 55 of 1993). The status of the central Mussel Creek population was moderate but declining. The status of Cox Lagoon (headwaters of Mussel Creek) was good in 1990 and likely retains that status due to coinciding efforts to protect Morelet's crocodiles (Crocodylus moreletii) in the lagoon. Mucklehany Lagoon (also headwaters of Mussel Creek) was close to large villages, yet difficult to access and was presumably in excellent condition. Both lagoons have now been protected by law, as are the sections of Mussel Creek immediately downstream (Statutory Instrument No. 55 of 1993). The Sibun River is close to the Western Highway, and by local reports, had been heavily overexploited. Its status was poor, but the section between Ferguson Bank and Sibun Bar became completely protected (Statutory Instrument No. 55 of 1993).

Dermatemys is present in the vast brackish Northern and Southern Lagoons, though in lower densities than implied by Moll (1986). Those lagoons and their tributaries are now protected (Statutory Instrument No. 55 of 1993). That entire area, sometimes called the Manatee Lagoons, is now legally 
a "Special Development Area", with a focus on ecotourism and protection.

In southern Belize, Dermatemys probably inhabits the short deep estuarine sections of all the larger rivers. Most important are the Rio Grande, the Temash River, and the Sarstoon (= Sarstun) River (which forms the boundary with Guatemala). Moll (1986) reported some exploitation in the Rio Grande, which was still occuring in 1993. The lower sections of the Temash and Sarstoon Rivers are now part of the National Park System (Temash and Sarstoon Delta Wildlife Sanctuary). By reports, the status of the Dermatemys populations in both is good.

The Maya of extreme southern Belize seem less focused on eating Dermatemys than the Creoles of the north. As a consequence there are presumably scattered pockets of Dermatemys that are thriving in the south. Similarly, now that the mahogany and chicle businesses have slowed, and the hide industry (crocodiles and spotted cats) is closed, some of the very remote smaller streams of north central and northwest Belize (formerly vital for transportation) receive little traffic, and may harbor some turtles of great size and antiquity.

In Belize, enforcement and compliance challenges remain: human consumption of D. mawii is still a common practice. In February 2009, Gonzalez-Porter (pers. obs.) observed, in just one morning, six families eating the species, and using up to four animals (mainly adult males) per family. All these turtles were collected by locals in the Belize River near Big Falls, while on the same day local fishermen were seen with seven juveniles from the Sibun River that they planned to raise in captivity and eat.

Little is known about the D. mawii populations in Quintana Roo, Mexico, but Calderón-Mandujano (pers. comm.) is currently assessing them and has found that some of these populations are in good shape, notably in the area of $\mathrm{La}$ Unión at Rio Hondo. Similar information was reported by García-Anleu (2007) at Laguna Peru, in Guatemala.

The status of the Guatemalan populations is poorly known. In the state of Izabal, the Rio Polochic - Lago Izabal - Rio Chocón Machaca complex probably constitutes the largest contiguous habitat for the turtle in its range. The status there is poorly known and urgently deserves investigation. In 1991, Jonathan Campbell (pers. comm.) noted that Dermatemys appeared to be very rare there, and on the brink of extirpation; he commented that the area previously had a thriving population in the $1960 \mathrm{~s}$. The presence and status of Dermatemys in the lengthy Rio Motagua near Honduras is unknown. In the Petén, it appears that Dermatemys has been eradicated from Lago Petén-Itza. However, it still occurs in Rio de la Pasión, where it is a popular food item. Its status there deserves investigation. Dermatemys occurs in the fairly remote Rio San Pedro in northern Petén, and other significant tributaries of the Rio Usumacinta system. About 200 Dermatemys from the Rio San Pedro and adjacent Lago Peru within the Lago de Tigre Reserve have been measured and marked (García-Anleu, unpubl. data). The population in Laguna Yaxha in northeastern Petén may be the best protected in the entire range of Dermatemys. The lake lies inside the Maya Biosphere Reserve. There is a well-staffed Consejo Nacional de Areas Protegidas (CONAP) field office on the south shore of the lake. Across the lake, the government archaeology office that administers the large Yaxha Mayan site provides additional management presence.

García-Anleu et al. (2007) found new records of distribution of D. mawii in the headwaters of Rio Azul in extreme northeastern Guatemala. According to them, Laguna Peru has the greatest density of this species of all localities they assessed in Guatemala. They reported that in 2006 they collected 113 individuals in 13 days of effort. They suspected that this Lagoon is a feeding and nesting refuge during the dry season (García-Anleu et al. 2007). In November 2009 García-Anleu and Vogt (unpubl. data) collected 20 adult Dermatemys in $6 \mathrm{hrs}$ in $150 \mathrm{~m}$ of gill net in Laguna Peru.

Threats to Survival. - The primary threat is direct mortality for human consumption. Although habitats are being degraded in some areas, typically Dermatemys populations have been overhunted well before that becomes a problem. In Mexico, overcollecting for the use of turtle meat as a delicacy in high-priced restaurants poses the greatest threat.Dermatemys were being sold in Villahermosa for \$US 4 per kg live weight in 1991, bringing the price of the meat to \$US 20 or more per kg, outpricing lobster. An average large female weighing $10 \mathrm{~kg}$ brought $\$$ US 40 . The price has continued to rise, and with it the motivation to exploit. In 2005 , two brothers, elderly men, were caught smuggling one Dermatemys adult per month by bus to Villahermosaone turtle brought the equivalent of one month's salary at minimum government wage. This emphasizes the fact that there are no longer large populations to be harvested, but the price is so high that no turtle will survive as long as there are people in the large cities willing to buy them for a high price. Perhaps as a result, there have been recent reports of Mexicans hunting Dermatemys in the rivers of northwest Belize. In Mexico, Dermatemys is heavily sought after for Lent, while in Belize it is a traditional Easter meal. Both special occasions occur in April, during the dry season. Low water levels and decreased turbidity increase capture efficiency, and the greatest numbers of turtles are captured and sold during this month. Pollution of rivers also can affect the species, making it impossible to restock it in some areas where it once thrived.

Most of the finer restaurants in Guatemala City, especially the steak houses, offer a soup made from Dermatemys. Soldiers stationed in the Petén often use the turtle for meat (J. Campbell, pers. comm.). Restaurants in Flores and Santa Elena, Petén, are no longer offering wildlife, including turtles, for sale; in fact some restaurants even state on their printed menus that they no longer serve wildlife (Vogt and García-Anleu, pers. obs., 2009).

Commercial exploitation has been the gravest threat in Belize as well. Though the profit has not been as great (in the early 1990s, the same turtle that could yield \$US 40 in Mexico, yielded \$US 10-12 in Belize), it has still been sufficient to motivate commercial exploitation. In Belize 
the turtle is hunted opportunistically all months of the year, with capture success being inversely correlated with the dynamic water levels. Exploitation peaks during the dry season, particularly from mid-March through May, when both subsistence and market hunters escalate their efforts due to greater likelihood of success.

The three methods used to capture Dermatemys are harpoons, nets, and free-diving. Harpoons (locally called pegs) are primarily used for subsistence hunting. Nets and diving are more likely to be used for the commercial collection of large numbers of Dermatemys. However, both are also used for small-scale subsistence hunting (Polisar 1992, 1995).

It is important to remember that in any area where human populations are high, even subsistence hunting might be more than turtle populations can endure. The level of sustainable use has not been defined for Dermatemys, but it is probably quite low. Human predation on large juveniles and adults appears to disrupt the conservative life history strategy of iteroparity based on high adult survivorship and longevity, and hunting mortality is probably additive, not compensatory (Polisar 1995).

Small-scale subsistence hunting does remove less animals, and $i s$ less deleterious than commercial harvesting (Polisar 1992, 1995, 1997). There are numerically more subsistence hunters, taking fewer turtles than commercial hunters. Unlike many commercial hunters, some subsistence hunters are interested in maintaining long-term availability. We need to work with the subsistence hunting constituency, and probably need to accommodate some of their interests, but we are not yet certain that the turtle can sustain even moderate use (Polisar 1995). In sparsely populated areas, subsistence use may not be detrimental. However, if Dermatemys occurred in an area of high human population density, and each family was allowed a reasonable subsistence take through a bag limit, there might be none left after the first day.

Conservation Measures Taken. - Dermatemys has been listed as Critically Endangered on the IUCN Red List since 2006, and is listed on Appendix II of CITES. It is also included in the Red Data Book of Protected Species of Mexico as an Endangered (NOM-ECOL-059) species.

In Mexico the species is protected, and its collection is illegal and requires a permit. However, the authorities do not have enough inspectors or guards to monitor the whole range of distribution of the species and in several cases these people lack training in turtle identification or animal management.

The environmental authority in Mexico has been promoting the sustainable use of turtles through local low cost turtle farms among the local communities, and D. mawii is among the species of high priority for these projects. At this point there are some turtle farms, mainly in the states of Veracruz, Tabasco, and Chiapas.

In Mexico, a closed season in Veracruz, Tabasco, Chiapas, and Campeche since 1975 has done little to stop the overcollection of Dermatemys. Captive reproduction in Tucta, near Villahermosa for restocking has been undertaken.
An educational program is ongoing in the rural communities that border the Biosphere Reserve of Montes Azules. The habitat requirements and home range of the population within Montes Azules are being studied to ensure the survival of all life stages.

In Guatemala, CONAP's 1992 draft calendar of hunting regulations stated that hunting and capturing Dermatemys was prohibited throughout the country (Gonzalez-Porter,pers. obs.). This is apparently an extension of an earlier policy, which Campbell (pers. comm.) felt was actually receiving scant enforcement.

Belize differs from its two neighbors in that, until 1993, use of Dermatemys was essentially unregulated. This allowed Polisar to conduct field research between 1989 and 1991 that examined the biology of the species, and also included the collection of exploitation and marketing data, allowing an assimilation of the socioeconomic realities and perspectives of market hunters, subsistence hunters, and vendors. Without any penalty for volunteering information or specimens to be measured, there was an abundance of local cooperation. Following the analysis of data and specimens Polisar conducted a follow-through trip in 1992 to disseminate information and deliver management recommendations. During that trip he addressed interested villages, government officials, and the conservation community through the dissemination of documents and slide shows.

In 1993, the Fisheries Department used the recommendations of Polisar (1992) and the village of Freetown Sibun when it drafted legislation protecting and managing Dermatemys throughout Belize (Statutory Instrument No. 55 of 1993) (Polisar 1994; Polisar and Horwich 1994). This legislation included year-round possession limits (which eliminated large-scale removals without negatively affecting small-scale hunting for personal use), a short closed season (1-31 May), a complete prohibition on selling and purchasing Dermatemys, and an extensive series of protected zones in the major waterways of northern Belize. In addition, the recently created Temash and Sarstoon Wildlife Sanctuary will protect two estuarine populations of Dermatemys in southern Belize.

Conservation Measures Proposed - - A new approach is needed to enforce the ban on collecting Dermatemys in Mexico. Enforcement should not focus on trying to apprehend and capture poor fishermen, but instead on placing substantial fines on the affluent people who eat Dermatemys in restaurants, as well as through forced closing of restaurants and prison sentences for restaurant owners who serve Dermatemys. It is necessary to remove the strong incentive posed by the extremely high prices that the urban elite are willing to pay.

Clearly this species requires attention in Guatemala. There is an urgent need for surveys of Rio Polochic, Lago Izabal, Rio Chocón-Machaca, and Rio Dulce in the department of Izabal. The same is needed for Rio de la Pasion, Rio San Pedro, Laguna del Tigre, and Laguna Yaxh in Petén. The latter introduces an oft-neglected point. Field research on large, highly aquatic and spatially dispersed herbivorous 
turtles such as Dermatemys presents logistic problems not often recognized in the scientific community's or the public's perception of turtle research. There are no communal nesting beaches, the turtles cannot be captured in small traps baited with sardines, and even a simple dry season survey such as described above involves considerable skilled manpower, transportation (trucks, boats, trailers, and outboard motors), and equipment (a full complement of large expensive nets and accessories). If free divers are employed they should be regarded as skilled laborers performing dangerous duties. Conducting capture efforts during the autumn floods for reproductive information introduces logistical and labor demands that far exceed most perceptions, and the work is expensive. The costs may be high, but if quality information is sought, they must be met.

The logical recommended extensions to recent advances in Belize are the following: 1) consultations with specific rural communities to fine-tune local regulations; 2) consultations with specific commercial hunters, so they have the opportunity to become compliant before suffering the dangers and indignities of incarceration for violations; 3) establishing formal and informal programs to monitor both compliance with regulations and long-term responses of the Dermatemys populations to changes in hunting intensity and complete protection; 4) development of accessible educational materials for dispersal through school systems, media, and environmental education institutions, emphasizing the uniqueness of the turtle and its proven vulnerability to overuse; and 5) education coupled with enforcement. In 2010 the Environmental Research Institute (ERI) of the University of Belize hosted a workshop in partnership with the Turtle SurvivalAlliance, the Belize Fisheries Department, and the Belize Foundation for Research and Environmental Education (BFREE), forming the Belize National Hicatee Conservation and Monitoring Network (NHCMN) which includes 20 member organizations. Coordinated and housed in the ERI, in 2011 the NHCMN considered in-country training on field monitoring a priority.

In view of the phylogeographic structure of the species, one should consider the populations from Sarstun, Guatemala, and Salinas, Mexico, as well as Papaloapan, Mexico, as separate Evolutionarily Significant Units (ESU), and the rest of the population as one Management Unit.

Captive Husbandry. - Experiments in Mexico suggest that hatchling Dermatemys are among the easiest turtles to raise in captivity. If they have been inoculated with their natural gut fauna by providing adult feces, they grow rapidly on leaves of composites or even dry forest leaves. They do not need to leave the water to bask or dry the shell, they do not require direct sunlight, nor do they require vitamin supplements. One must take into consideration the delicate nature of the plastron and provide tanks which do not have abrasive surfaces such as cement. Plastic or rustic earth tanks are preferred. Since they are not fond of crawling out on land, earth tanks with steep banks are sufficient to retain them, as long as there is an outlet to prevent the tanks from overflowing during heavy rains. Adults will feed on a variety of fruits and vegetables, but seem to do better feeding on natural grasses and leaves which their natural gut symbionts have evolved to digest for them. It is important to keep sufficient food available at all times so that they can maintain the populations of these symbionts at efficient levels. Experiments at polyculture with freshwater shrimp (Macrobrachium rosenbergi) were successful in earth ponds in Veracruz. The turtles keep the ponds clean from invading grasses and other plants, fertilize the water with their feces, and do not harm the prawns. After all of the invading vegetation was consumed the turtles were fed grass clippings for 3 years and reproduced each year under those conditions. When kept out of water for any length of time they were highly susceptible to a bacterial lung infection.

The turtle farm in Nacajuca, Tabasco, is the largest captive breeding facility for Dermatemys in Mexico; it contains a population of about 800 individuals. This farm has served as a rescue center since its creation in the 1980s, but lacks a proper management plan for these animals. The animals have been kept in a single tank for more than 25 years, and record-keeping for individuals is very poor, making it almost impossible to design a good reintroduction program for these individuals or their offspring. Rangel-Mendoza et al. (2009) conducted a hematological study comparing animals from this farm and the wild, showing that the captives were in poor physical condition while the wild turtles were apparently healthy.

Current Research. - Vogt continues to monitor populations in Chiapas, studying growth and fecundity in natural populations, number of years to reach maturity, male reproductive cycle, movements, home range, and developing a polyculture sustainable yield management system. Recently, Thomas Rainwater and colleagues have conducted a country-wide survey on the present status of Dermatemys in Belize (Rainwater et al., in press). GonzalezPorter is currently working on the conservation genetics of this species throughout its geographic range. García-Anleu is currently working on D. mawii distribution and ecology of populations along the San Pedro River as well as census and population status throughout the former range of the species in Guatemala. Calderon-Mandujano is working on a population assessment of D. mawii in the southern part of Quintana Roo. García-Anleu and Vogt in 2009 conducted a home range and habitat use study of Dermatemys in Rio San Pedro and Lago de Peru in the El Tigre Reserve, Petén, Guatamala, where they are monitoring 10 adults with radiotransmitters.

Acknowledgments. - Vogt thanks Marcelo Paxtian Sinaca and Jose Louis Villareal Benitez for their indispensable help in both the field and laboratory aspects of the study providing the data for this account. Funding was provided by Conservation International, the Program for Tropical Studies at the University of Florida, Estacion de Biologia Tropical Los Tuxtlas, Instituto de Biologia de Universidad Nacional Autonoma de Mexico, Carnegie Museum of Natural History, and CONACYT (Proyecto 084 N9196). 
Polisar's research was funded by NYZS/The Wildlife Conservation Society, Chelonia Institute, Programme for Belize, Lincoln Park Zoo, IFAS International Programs, and the Program for Studies in Tropical Conservation at the University of Florida, Manomet Bird Observatory, and Sigma Xi. Support for follow-through work came from the Chelonia Institute, Crystal Channel Foundation, Fossil Rim Foundation, and the Tropical Conservation and Development Program at the University of Florida. Logistical assistance is credited to the Community Baboon Sanctuary, Belize Audubon Society, Belize Center for Environmental Studies, Chau Hiix Lodge, Belize Meteorological Service and Hydrology Department, Lighthawk, and British Forces Belize. The Belize Forestry Department, Fisheries Department, and Conservation Division cooperated in many ways. F. Wayne King provide academic supervision and suggestions regarding conservation strategies. Louis J. Guillette, Jr. provided guidance through the ovaries. Special thanks goes to over 75 residents of the villages of rural northern Belize. Their cooperation and assistance made the project possible.

Moll's research was funded by World Wildlife Fund-US, the Southwest Missouri State University Faculty Research Fund, the SMSU Foundation, and the Fauna and Flora and Preservation Society. Leonard E. Dieckman of St. Johns College, Lydia Waight of the Belize Audubon Society, Alan Burn, and Otto and Thea Maraun all facilitated his work.

\section{LITERATURE CITED}

Alvarez del Toro, M. 1982 Los Reptiles de Chiapas. Tercera Edicion, corregida y aumentada. Tuxtla Gutierrez: Instituto Historia Natural, 248 pp.

Alvarez del Toro, M., Mittermeier, R.A., AND Iverson, J.B. 1979 River turtle in danger. Oryx 15(2):170-173.

BEGON, M. 1979. Investigating animal abundance: capture recapture for biologists. London: Edward Arnold.

BIENZ, A. 1896. Dermatemys mavii Gray, eine osteologische Studie mit Beitragen zur Kenntnis der Schildkroten. Revue Suisse de Zoologie 3:61-135.

BJoRndal, K.A. AND Bolten, A.B. 1990. Digestive processing in a herbivorous freshwater turtle: consequences of small intestine fermentation. Physiological Zoology 63:1232-1247

Boulenger, G.A. 1889. Catalogue of the Chelonians, Rhynchocephalians, and Crocodiles in the British Museum (Natural History). London: Taylor and Francis, $311 \mathrm{pp}$.

Buhlmann, K.A., Akre, T.S.B., Iverson, J.B., Karapatakis, D., MitTERmeier, R.A., Georges,A., Rhodin, A.G.J., van DiJk, P.P., AND GibBons, J.W. 2009. A global analysis of tortoise and freshwater turtle distributions with identification of priority conservation areas. Chelonian Conservation and Biology 8(2):116-149.

Caballero y Caballero, E. 1942. Trematodos de las tortugas de Mexico. II. Descripcion de un nuevo genero de la familia Pronocephalidae Looss, 1902 y descripcion de una nueva especie del genero Octangioides Price, 1937. Anales Instituto Biologia Universidad Nacional Mexico 13(1):81-90.

Caballero y Caballero, E. 1961. Trematodos de las tortugas de México. VIII. Descripcion de un nuevo genero que parasita a tortugas de agua dulce. Ciencia 21(2):61-64.

Caballero y Rodriguez, G. 1960. Estudio de trematodos digeneos de algunas tortugas comestibles de Mexico.Ph.D. Thesis, Universidad
Nacional Autonoma, Mexico.

CARR, J.L., BickHAM, J.W., AND DEAN, R.H. 1981. The karyotype and chromosomal banding patterns of the Central American river turtle Dermatemys mawii. Herpetologica 37(2):92-95.

Chablé-Santos, J.B., Chuma-Segura, L., and Selem-Salas, C. 2011. Dermatemysmawii(CentralAmericanRiverTurtle).Herpetological Review 42(2):238.

COPE, E.D. 1865. Third contribution to the herpetology of tropical America. Proceedings of the Academy of Natural Sciences of Philadelphia 17:185-198.

Cope, E.D. 1868. An examination of the Reptilia and Batrachia obtained by the Orton expedition to Equador and the upper Amazon, with notes on other species. Proceedings of the Academy of Natural Sciences of Philadelphia 20:96-140.

DuméRIL,A.M.C. And BiBRon,G. 1851.[Emys berardii].In: Duméril, A.M.C. and Duméril,A.H.A.Catalogue Methodique de la Collection des Reptiles (Museum d'Histoire Naturelle de Paris). Paris: Gide and Baudry, 224 pp. [p. 11].

García-ANLeu,R.,McNab,R.,SotoShoender,J.,EsPeJel,V.,Moreira, J.,Ponce, G., Ramos, V.H., Oliva,F., González,E., Tut,H., Tut,K., Xol, T., Xol,P., Córdova, M., AND Morales, L. 2007. Distribution and ecology of the CentralAmericaRiverTurtle(Dermatemys mawi: Dermatemidae) in the lowland Maya forest, Guatemala. Wildlife Conservation Society-Guatemala Program Internal Report.

Gonzalez-Porter, G.,Hailer,F., Flores-Villela, O., Garcia-Anleu, R., And Maldonado, J. 2011. Patterns of genetic diversity in the critically endangered CentralAmerican riverturtle: humaninfluence since the Mayan age?Conservation Genetics 12:1229-1242, doi 10.1007/s10592-011-0225-x.

GRAY, J.E. 1847. Description of a new genus of Emydae. Proceedings of the Zoological Society of London 1847:55-56.

GRAY, J.E. 1856 ["1855”]. Catalogue of Shield Reptiles in the Collection of the British Museum. Part I. Testudinata (Tortoises). London: British Museum, 79 pp.

GRAY, J.E. 1870. On the family Dermatemydae, and a description of a living species in the gardens of the Society. Proceedings of the Zoological Society of London 1870:711-716.

GRAY, J.E. 1873. Hand-List of the Specimens of Shield Reptiles in the British Museum. London: British Museum, 124 pp.

Holman, J.A. 1963. Observations on dermatemyid and staurotypine turtles from Veracruz, Mexico. Herpetologica 19(4):277-279.

Hutchison, J.H. AND BRAmBLE, D.M. 1981. Homology of the plastral scales of the Kinosternidae and related turtles. Herpetologica 37:73-85.

IVERSON, J.B. 1992.ARevised Checklist with Distribution Maps of the Turtles of the World. Richmond, IN: Privately printed, $363 \mathrm{pp.}$

IVERSON,J.B.AND MITTERMEIER,R.A.1980.Dermatemydidae,Dermatemys. Catalogue of American Amphibians and Reptiles 237:1-4.

LEE, R.C. 1969. Observing the tortuga blanca. International Turtle and Tortoise Society Journal 3(3):32-34.

McDowell, S.B. 1964. Partition of the genus Clemmys and related problems in the taxonomy of the aquatic Testudinidae. Proceedings of the Zoological Society of London 143(2):239-279.

Meylan, P.A., Schuler, R., and Moler, P. 2002. Spermatogenic cycle of the Florida softshell turtle, Apalone ferox. Copeia 2002(3):779-786.

MoLl, D. 1986. The distribution, status, and level of exploitation of the freshwater turtle Dermatemys mawei in Belize, Central America. Biological Conservation 35:87-96.

Moll, D. 1989. Food and feeding behavior of the turtle, Dermatemys mawei, in Belize. Journal of Herpetology 23(4):445-447.

NeILl, W.T. and Allen, E.R. 1959. Studies on the amphibians and reptiles of British Honduras. Publications of the Research Division 
of the Ross Allen Reptile Institute 2(1):1-76.

POLISAR, J. 1992. Reproductive biology and exploitation of the Central American river turtle Dermatemys mawii in Belize. Masters Thesis, University of Florida, Gainesville.

PolisAR, J. 1994. New legislation for the protection and management of Dermatemys mawii in Belize, Central America. Herpetological Review 25:47-49.

POLISAR,J.1995.Riverturtlereproductive demography andexploitation patterns in Belize: implica-tions for management. Vida Silvestre Neotropical 4:10-19.

PolisAR, J. 1996. Reproductive biology of a flood-season nesting freshwater turtle of the northern neotropics: Dermatemys mawii in Belize. Chelonian Conservation and Biology 2(1):13-25.

Polisar, J. 1997. Effects of exploitation on Dermatemys mawii populations in northern Belize and conservation strategies for rural riverside villages. In: Van Abbema, J. (Ed.). Proceedings: Conservation, Restoration, and Management of Tortoises and Turtles - An International Conference. N.Y. Turtle and Tortoise Society, pp. 441-443.

PolisAr, J. AND HoRwich, R. 1994. Conservation of the large economically important river turtle Dermatemys mawii in Belize. Conservation Biology 8:338-342.

Rainwater, T.R.,Pop,T., Cal, O., Garel,A.,Platt, S.G., and Hudson, R. In press. A recent country-wide status survey of the Critically Endangered Central American River Turtle (Dermatemys mawii) in Belize. Chelonian Conservation and Biology 11(1).

Rangel-Mendoza, J., Weber, M., Zenteno-Ruiz, C.E., Lopez-Luna, M.A.,ANDBARBA-MACIAS,E.2009.Hematology and serumbiochemistry comparison in wild and captive Central American river turtles (Dermatemys mawii) in Tabasco, Mexico. Research in Veterinary Science 87:313-318.

ROMER,A.S. 1956.The Osteology of the Reptiles. Chicago: University of Chicago Press, 772 pp.

SMith, H.M. AND TAYLOR, E.H. 1950. An annotated checklist and key to the reptiles of Mexico exclusive of the snakes. United States National Museum Bulletin 199:1-253.

SMith, H.M. And SMIth, R.B. 1980. Synopsis of the Herpetofauna of Mexico. Volume VI. Guide to Mexican Turtles. Bibliographic Addendum III. North Bennington, Vermont: John Johnson, 1044 pp.

Statutory Instrument No. 55 of 1993. Fisheries (Amendment) Regulations. Belmopan: Government of Belize, 4 pp.

ThatchER, V.E. 1963. Trematodes of turtles from Tabasco, Mexico, with a description of a new species of Dodaytrema (Trematoda: Paramphistomidae). American Midland Naturalist 70:347-355.

TROYER, K. 1982. Transfer of fermentation microbes between generations in a herbivorous lizard. Science 216:540-542.

Vogt, R.C. 1988. Ecologia y status de la tortuga blanca Dermatemys mawei. Reporte Tecnico Final de Proyecto, CONACyT, Mexico, 22 pp.

VoGT, R.C. 1998. Ecologia de las comunidades y estatus de las poblaciones de tortugas dulceacuicolas del sureste de Mexico. Proyecto SIGOLFO 96-06-040-v. Jalapa, Veracruz, 28 pp.

Vogt, R.C. AND Flores-VILlela, O. 1992a. Aspectos de la ecologia de la tortuga blanca Dermatemys mawii en La Reserva de Montes Azules, Chiapas. Reserva de la Biosfera Montes Azules, Selva Lacandona: Investigacion parasu Conservacion.Publicacion Especial Ecosfera 1:221-132.

VoGt, R.C. AND FloRES-VILLELA, O. 1992b. Effects of incubation temperature on sex determination in a community of neotropical freshwater turtles in southern Mexico. Herpetologica 48(3):265-270.

WaAgen, G.N. 1972. Musk glands in Recent turtles. Masters Thesis, University of Utah, Salt Lake City, Utah.

Werner, F. 1901. Neue Reptilien des Königsberger zoologischen Museums. Zoologischer Anzeiger 24:297-301.

WINOKUR, R.M. 1988. The buccopharyngeal mucosa of the turtles (Testudines). Journal of Morphology 196:33-52.

Zenteno Ruiz, C.E., Barba Macias, E., Bello-Gutiérrez, J., and OchoA-Gaona, S. 2010. Caracterización espacio-temporal y preferencias del hábitat de Dermatemys mawii (Testudines: Dermatemydidae) en la cuenca del Grijalva-Usumacinta, Tabasco, México. Revista de Biología Tropical 58(4):1247-1260.

\section{Citation Format for this Account:}

Vogt, R.C., Polisar, J.R., Moll, D., and Gonzalez-Porter, G. 2011. Dermatemys mawii Gray 1847 - Central American River Turtle, Tortuga Blanca, Hickatee. In: Rhodin, A.G.J., Pritchard, P.C.H., vanDijk,P.P.,Saumure,R.A.,Buhlmann,K.A.,Iverson,J.B., and Mittermeier, R.A.(Eds.). Conservation Biology of Freshwater Turtles and Tortoises: A Compilation Project of the IUCN/SSC Tortoise andFreshwaterTurtleSpecialistGroup.Chelonian Research Monographs No. 5, pp. 058.1-058.12, doi:10.3854/crm.5.058. mawii.v1.2011, http://www.iucn-tftsg.org/cbftt/. 